\title{
PCR identification of Petunia male sterile cytoplasm
}

\author{
Noemí Colombo ${ }^{1 *}$, Juan Carlos Hagiwara²
}

\begin{abstract}
Petunia is a very important ornamental plant with a broad range of flower colour and size, and most of the cultivars grown are propagated through seeds. Cytoplasmic male sterility (CMS) is a maternally inherited character determined by mitochondrial genes that results in impaired pollen development. The unique and well characterized male sterile cytoplasm in Petunia is a valuable resource for hybrids production because it prevents self-fertilization of mother plants and ensures the purity of F1s. Introgression of the male sterile cytoplasm in elite lines of Petunia is achieved following a backcross scheme and can be assisted using molecular markers associated to the trait of interest. The objective of this study was to develop a molecular marker to identify the male sterile cytoplasm of Petunia. A PCR-based marker amplifying a region of the mitochondrial CMS-associated urfS only in the male sterile plants was designed. Results showed differential PCR amplification of a $\approx 600$ bp product in plants carrying male sterile cytoplasm in four Petunia species and their F1s and BC1 generations. A multiplex PCR reaction was subsequently set up, adding specific primers amplifying a $\approx 800$ bp product from the conserved region trnT-trn- $L$ of the chloroplast genome as a positive control in order to unambiguously identify the cytoplasm types as normal or sterile. A rapid, simple and precise molecular marker is now available for assisting breeding of F1 hybrids in Petunia.
\end{abstract}

Keywords: Petunia spp; cytoplasmic male sterility; molecular markers; ornamental plant breeding

\section{Resumo}

\section{Identificação por PCR de citoplasma macho estéril em Petunia}

A petúnia é uma planta ornamental muito importante, com uma ampla gama de cores e tamanhos de flores, e a maioria das cultivares são propagadas através de sementes. A esterilidade citoplasmática masculina (CMS) é um caráter hereditário da mãe, determinado por genes mitocondriais que resultam em prejuízo ao desenvolvimento do pólen. O citoplasma macho estéril único e bem caracterizado em Petúnia é um recurso valioso para a produção de híbridos, pois previne a autofecundação das plantasmãe e garante a pureza do F1. A introgressão do citoplasma macho estéril nas linhas de elite de Petúnia é alcançada seguindo um esquema de retrocruzamento e pode ser assistida usando marcadores moleculares associados à característica de interesse. $\mathrm{O}$ objetivo deste estudo foi desenvolver um marcador molecular para identificar o citoplasma macho estéril de Petunia. Foi desenhado um marcador baseado em PCR que amplificou uma região de urfS associada à CMS mitocondrial apenas em plantas masculinas estéreis. Os resultados mostraram amplificação por PCR diferencial de um produto de $\approx 600 \mathrm{bp}$ em plantas portadoras de citoplasma estéril masculino em quatro espécies de Petúnia e suas gerações F1s e BC1. Uma reação de PCR multiplex foi subsequentemente configurada, adicionando iniciadores específicos amplificando um produto de $\approx 800$ bp da região conservada trnT-trn-L do genoma do cloroplasto como um controle positivo, para identificar inequivocamente os tipos de citoplasma como normal ou estéril. Um marcador molecular rápido, simples e preciso está agora disponível para auxiliar no melhoramento genético de híbridos $\mathrm{F} 1$ em Petunia.

Palavras-chave: Petunia spp; esterilidade citoplasmática masculina; marcadores moleculares; melhoramento de plantas ornamentáis

\footnotetext{
${ }^{1}$ Instituto de Genética "Ewald A. Favret”, CICVyA, INTA, Hurlingham, Buenos Aires, Argentina.

*Corresponding autor: colombo.noemi@inta.gob.ar

${ }^{2}$ Instituto de Floricultura, CIRN, INTA, Hurlingham, Buenos Aires, Argentina
} 


\section{Introduction}

Cytoplasmic male sterility (CMS) is a trait resulting from the expression of mitochondrial genes which impair the normal development of pollen. As in most angiosperms mitochondria genome is maternally inherited (Corriveau and Coleman, 1988; Mogensen, 1996), CMS is maternally transmitted as well. This condition can be suppressed by the effect of nuclear genes known as restorers of fertility $(R f)$ genes. CMS $/ R f$ systems have been widely used in plant breeding to increase the efficiency of hybrid production in several crops (Bohra et al., 2016; Kim and Zhang, 2018). In the case of ornamental species CMS is a desirable trait for breeding purposes to produce hybrid seed, to increase flowering duration, to avoid pollen allergens and to control invasiveness (Colombo et al., 2017).

Petunia (Petunia hybrida) is a very important ornamental plant in worldwide horticulture. It is characterized by its diversity in flower colour and morphology. It is the world's most popular bedding plant and in the United States, it ranks first in wholesale value among annual bedding plant crops. There are numerous commercial cultivars and most of them propagate through seeds (Ganga et al., 2011; Cao et al., 2019).

The only male sterile cytoplasm described in the genus Petunia (Izhar, 1978) has been associated with a mitochondrial chimeric gene termed $p c f$, which includes portions of the coding regions of atp 9 , coxll and an unidentified ORF named urfS. In the presence of the dominant nuclear gene $R f$ the $p c f$ transcript profile is altered and the amount of the PCF protein is greatly reduced resulting in male fertility restoration (Young and Hanson, 1987; Bentolila et al., 2002; Gillman et al., 2009).

The line 3688 of Petunia axillaris (Lam.) Britton, Stern \& Poggenb. ssp. Parodii (Steere) Cabrera, carrying the male sterile cytoplasm, has been used in intra and interspecific crosses by different genotypes of the Petunia breeding program at INTA, in order to start the development of different cytoplasmic male sterile lines. The introgression of the male sterile cytoplasm is achieved following a backcross scheme, using the pollen donor of the crosses as the recurrent parent. Molecular identification of cytoplasm types has proved helpful to assist the development of male sterile lines as well as to determine hybrid seed purity in different crops (Dwivedi et al., 2008; Bohra et al., 2016). Although marker assisted selection has been applied for different characters in several ornamental crops (Debener, 2001; Aswath and Thaneshwari, 2017) no molecular marker associated with Petunia male sterile cytoplasm is available so far. The objective of this work was to develop a molecular marker to identify Petunia male sterile cytoplasm.

\section{Materials and methods}

\section{Plant material}

The germplasm used in this study includes the line 3688 of Petunia axillaris ssp. parodii carrying the male sterile cytoplasm (S) and 5 male fertile lines of $P$. axillaris $s s p$. parodii, $P$. interior, $P$. hybrida and P. integrifolia, carrying normal cytoplasm $(\mathrm{N})$. Crosses were made between 3688 as the female parent and 4 pollen donors producing 4 F1s and one BC1 generations; all the progenies carry the male sterile cytoplasm due to the maternal inheritance of the character. In Table 1 the genotypes used and their cytoplasm types are shown.

\section{Molecular analysis}

Genomic DNA was extracted according to Doyle and Doyle (1987) from young leaves of plants of all the genotypes described in Table 1 grown in the greenhouse. The specific mitochondrial primers urfS-F: 5'-AGACTTGGACCCGAGCTTTT-3' and urfS-R: 5'-TCTTTTCCCATTCAGCCATC-3' were designed based on the sequence of urfS (Nivison et al., 1994) using the program Primer 3. The expected PCR product was 588 bp. PCR amplification was carried out in a final volume of $25 \mu \mathrm{l}$, with $20 \mathrm{ng}$ of genomic DNA; 20 $\mathrm{mM}$ Tris- $\mathrm{HCl} \mathrm{pH} 8.4,50 \mathrm{mM} \mathrm{KCl} ; 1.5 \mathrm{mM} \mathrm{Mg} \mathrm{Cl} ; 0.2$ $\mathrm{mM}$ each dNTPs; $0.12 \mu \mathrm{M}$ of each primer and $1 \mathrm{U}$ Taq polimerase (Invitrogen ${ }^{\mathrm{TM}}$ ). The thermal profile was 94 ${ }^{\circ} \mathrm{C}$ for $3 \mathrm{~min} ; 35$ cycles at $94{ }^{\circ} \mathrm{C}$ for $30 \mathrm{~s} ; 58{ }^{\circ} \mathrm{C}$ for 15 s; $72{ }^{\circ} \mathrm{C}$ for $30 \mathrm{~s}$ and a final extension at $72{ }^{\circ} \mathrm{C}$ for 10 min. Another PCR was performed using the universal primers F:5'-CATTACAAATGCGATGCTCT-3' and R: 5'-TCTACCGATTTCGCCATATC-3' to amplify the chloroplast intergenic region $\operatorname{trnT}$-trnL (Taberlet et al., 1991). In this case, the thermal profile was $94^{\circ} \mathrm{C}$ for $3 \mathrm{~min}$; 35 cycles at $94{ }^{\circ} \mathrm{C}$ for $1 \mathrm{~min} ; 55^{\circ} \mathrm{C}$ for $30 \mathrm{~s} ; 72^{\mathrm{a}} \mathrm{C}$ for 1 min and a final extension at $72^{\circ} \mathrm{C}$ for $10 \mathrm{~min}$. A multiplex PCR was made including both pairs of primers $-0.2 \mathrm{mM}$ each- with the following thermal profile: $94^{\circ} \mathrm{C}$ for $3 \mathrm{~min}$; 35 cycles at $94{ }^{\circ} \mathrm{C}$ for $30 \mathrm{~s} ; 58{ }^{\circ} \mathrm{C}$ for $30 \mathrm{~s} ; 72^{\circ} \mathrm{C}$ for $30 \mathrm{~s}$ and a final extension at $72{ }^{\circ} \mathrm{C}$ for $10 \mathrm{~min}$. PCR products were visualized under UV light after electrophoresis in $1.5 \%$ agarose gels stained with ethidium bromide. 
Table 1. List of analysed genotypes and their cytoplasm type: male fertile (F) or male sterile (S).

\begin{tabular}{|c|c|c|c|}
\hline $\mathbf{N}^{\circ}$ & Identification & Description & Cytoplasm type \\
\hline 1 & 3688 & $\begin{array}{l}\text { Petunia axillaris (Lam.) Britton, Stern \& Poggenb. ssp. parodii (Steere) } \\
\text { Cabrera. Dr. M. Hanson, Cornell University, Ithaca, N.Y., EEUU }\end{array}$ & $\mathrm{S}$ \\
\hline 2 & $20111128 \mathrm{C} 1$ & $\begin{array}{l}\text { P. axillaris (Lam.) Britton, Stern \& Poggenb. ssp. parodii (Steere) } \\
\text { Cabrera.(Mercedes, Corrientes, Argentina) }\end{array}$ & $\mathrm{F}$ \\
\hline 3 & $20131025 \mathrm{~A} 1$ & $\begin{array}{c}\text { P. interior Ando \& Hashim..(Gral.Manuel Belgrano, Misiones, } \\
\text { Argentina) }\end{array}$ & $\mathrm{F}$ \\
\hline 4 & 15-206\#2@ & P. hybrida & $\mathrm{F}$ \\
\hline 5 & 15-232\#1@ & P. hybrida & $\mathrm{F}$ \\
\hline 6 & 20151125A1 & $\begin{array}{l}\text { P. axillaris (Lam.) Britton, Stern \& Poggenb. ssp. parodii (Steere) } \\
\text { Cabrera. (San Jerónimo, Santa Fe, Argentina) }\end{array}$ & $\mathrm{F}$ \\
\hline 7 & 20151129A1 & $\begin{array}{l}\text { P. integrifolia (Hook.) Schinz \& Thell. ssp. Integrifolia. (Gral. San } \\
\text { Martín, Misiones, Argentina) }\end{array}$ & $\mathrm{F}$ \\
\hline 8 & $3688 \times 20131025 \mathrm{~A} 1$ & Petunia axillaris ssp. parodii $3688 \times$ P. interior & S \\
\hline 9 & 3688x15-206\#2@ & Petunia axillaris ssp. parodii $3688 \times$ P. hybrida & $\mathrm{S}$ \\
\hline 10 & 16-164x 15-232\#1@ & (Petunia axillaris ssp. parodii 3688 x 15-232\#1@) x P. hybrida & S \\
\hline 11 & $3688 \times 20151125 \mathrm{~A} 1$ & Petunia axillaris ssp. parodii $3688 \times$ P. axillaris ssp. parodii & $\mathrm{S}$ \\
\hline 12 & $3688 \times 20151129 A 1$ & Petunia axillaris ssp. parodii $3688 \times$ P. integrifolia & $\mathrm{S}$ \\
\hline
\end{tabular}

\section{Results}

\section{Amplification of the urfS region}

Specific primers were designed on the urfS region of the mitochondrial chimeric gene $p c f$ associated to CMS in Petunia. As expected, plants of the line 3688 carrying the male sterile cytoplasm amplified a product of $\approx 600$ bp corresponding to a region of urfS. F1 and BC1 plants from crosses using 3688 as the mother plant inherited the male sterile cytoplasm maternally and therefore they amplified the same $\approx 600$ bp product. On the contrary, no amplification product was observed in plants from the lines carrying the fertile cytoplasm (Figure 1). The lack of PCR product in plants with fertile cytoplasm suggests the need of a positive control in the same PCR reaction to discard any PCR failure. 


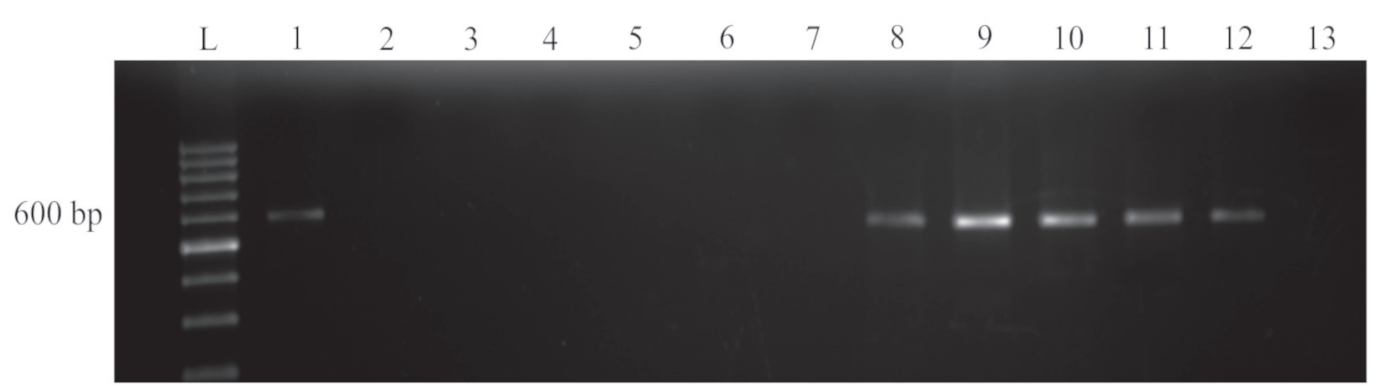

Figure 1. PCR identification of cytoplasm types in Petunia. L: 100 bp DNA ladder; Lanes 1 to 12 correspond to genotypes mentioned in Table 1; lane 13: negative control

Amplification of the chloroplast intergenic region trnT-trnL

In order to test for the suitability of the chloroplast intergenic region trnT-trnL as a positive control, universal primers were first tried separately. Plants carrying both cytoplasm types amplified a product of $\approx 800$ bp (Figure 2 ), thus proving appropriate as a positive control in a multiplex PCR reaction.

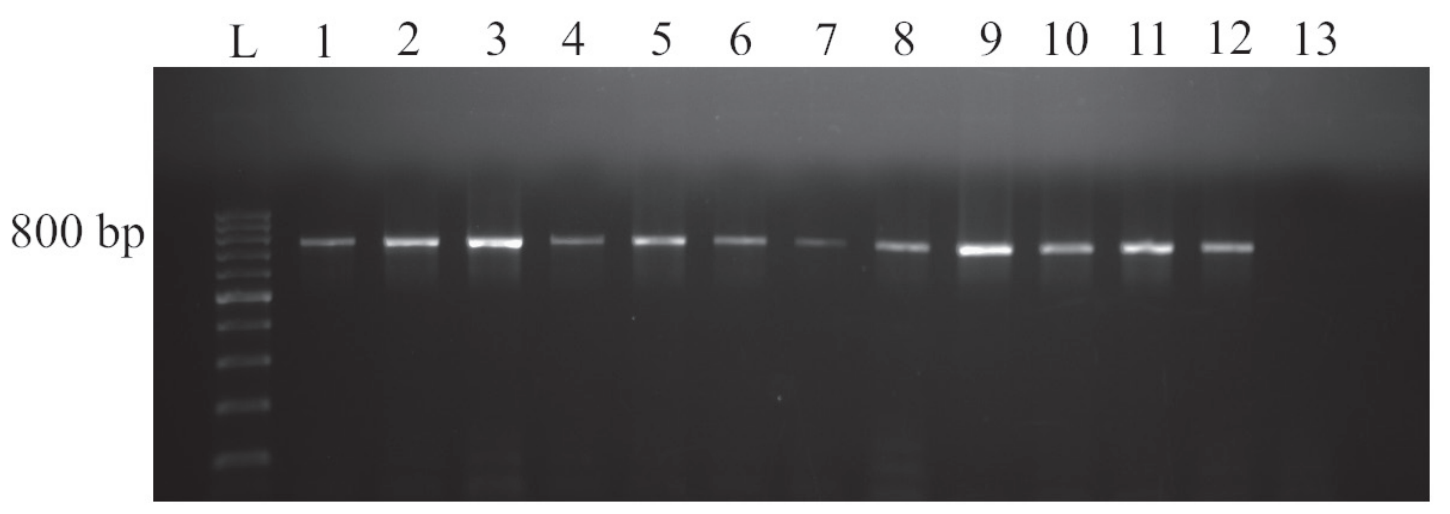

Figure 2. PCR identification of the chloroplast intergenic region trn-T-trnL in Petunia. L: 100 bp DNA ladder; Lanes 1 to 12 correspond to genotypes mentioned in Table 1; lane 13: negative control

\section{Multiplex PCR}

A multiplex PCR including both urf-S and trnT-trnL primers in the same reaction was set up. As expected, plants of all the analysed genotypes amplified the chloroplast intergenic region as a product of $\approx 800 \mathrm{bp}$. Besides, plants carrying the male sterile cytoplasm amplified both the chloroplastic intergenic region trnT-trnL and the mitochondrial urfS target (Figure 3).

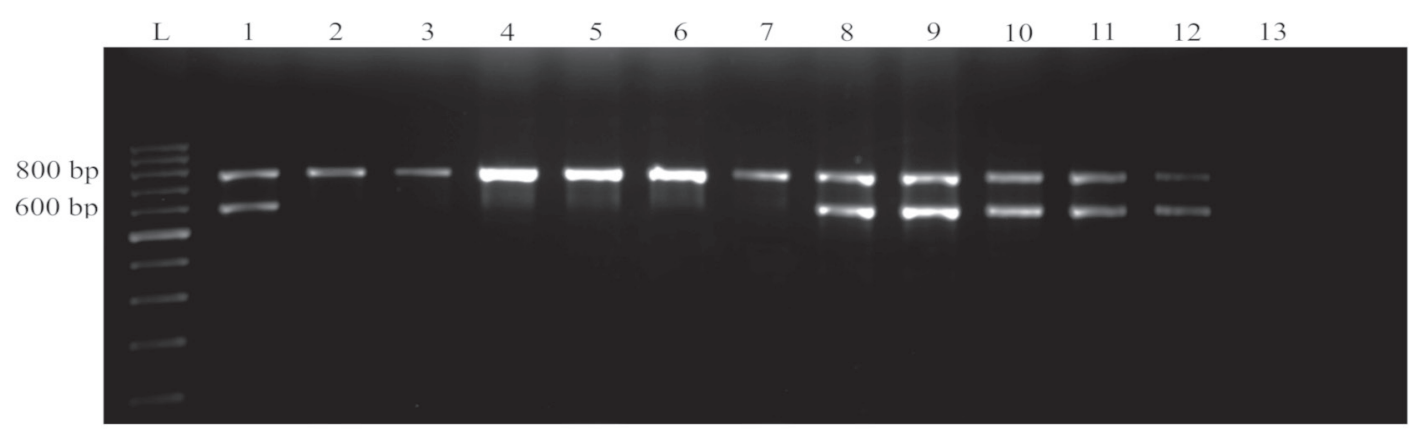

Figure 3. Multiplex PCR identification of cytoplasm types in Petunia. L: 100 bp DNA ladder; Lanes 1 to 12 correspond to genotypes mentioned in Table 1; lane 13: negative control 


\section{Discussion}

Petunia F1 hybrids lead the commercial offer of cultivars due to their superior vigour, uniformity, and performance (Ganga et al., 2011). A cost-efficient hybrid production system requires a reliable pollination control to avoid selffertilization of female plants. Some Petunia species, like $P$. integrifolia, are invariably self-incompatible; others, like P. hybrida are predominantly self-compatible (Robbins et al., 2000). In Petunia axillaris the ssp. axillaris is mostly self-incompatible but the ssp. parodii and subandina are entirely self-compatible (Tsukamoto et al., 2003). A wellcharacterized male sterile cytoplasm which prevents pollen development is available in Petunia (Gillman et al., 2009) and can be transferred by backcross to elite female lines in a breeding program. In this context, molecular markers associated to cytoplasm types are of value to trace sterile cytoplasms during their introgression into elite lines and to determine genetic purity of F1s (Shu et al., 2016; Swamy et al., 2017; Ferreira and Santos, 2018).

The differential PCR amplification of $\mathrm{a} \approx 600 \mathrm{bp}$ product, corresponding to a region of the CMS-associated $\operatorname{urfS}$, allowed the identification of male sterile and male fertile cytoplasm types in agreement with plant phenotypes in all the analysed Petunia lines, the F1s and the BC1 generations. However, due to the dominant nature of this marker, a positive control was later included in a multiplex PCR reaction to identify the normal cytoplasms undoubtedly. Amplification of the positive control ensures that the absence of product observed when amplifying the region of the CMS-associated urfS is not due to a failure in the PCR reaction. The highly conserved chloroplast intergenic region trnT-trnL previously amplified in a wide range of taxa (Taberlett, 1991) served as a positive control in the PCR reaction and permitted the precise identification of both cytoplasm types.

\section{Conclusions}

A simple and rapid PCR-based marker was developed to clearly identify the male sterile cytoplasm of Petunia.

This marker will be of help in Petunia hybrid breeding to ensure the purity of male sterile lines and F1 hybrids.

\section{Author Contribution}

N.C. ${ }^{0000-0002-8269-6034}$ and J.C.H. ${ }^{0000-0003-1472-9516}$ : planning the experiments, obtaining and analyzing data and writing the article.

\section{Acknowledgments}

We are thankful to S. Izhar and M. R. Hanson for kindly providing the seeds of the line 3688 and for their valuable suggestions. This work was supported by PNHFA-1106092, Instituto Nacional de Tecnología Agropecuaria, INTA, Argentina. The funding sources were not involved in the design of the study, in the collection, analysis or interpretation of data, in writing the report, or in the decision to submit the paper for publication.

\section{References}

ASWATH, C.; THANESHWARI. Biotechnological applications in floriculture. In: MALHOTRA, S. K.; RAM LALLAN. Advances in Floriculture and Landscape Gardening. Medziphema: Central Institute of Horticulture, 2017. p.73-80.

BENTOLILA, S.; ALFONSO, A.A.; HANSON, M.R. A pentatricopeptide repeat-containing gene restores fertility to cytoplasmic male sterile plants. Proceedings of the National Academy of Sciences of the United States of America, v.99, n.16, p.10887-10892, 2002. DOI: https:// doi.org/10.1073/pnas.102301599

BOHRA, A.; JHA, U.C.; ADHIMOOLAM, P.; BISHT, D.; SINGH, N.P. Cytoplasmic male sterility (CMS) in hybrid breeding in field crops. Plant Cell Reports, v.35, n.5, p.967-993, 2016. DOI: https://doi.org/10.1007/s00299016-1949-3

CAO, Z.; GUO, Y.; YANG, Q.; HE, Y.; FETOUH, M.I.; WARNER, R.M.; DENG, Z. Genome-wide identification of quantitative trait loci for important plant and flower traits in petunia using a high-density linkage map and an interspecific recombinant inbred population derived from Petunia integrifolia and P. axillaris. Horticulture Research, v.6, article 27, 2019. DOI: https://doi. org/10.1038/s41438-018-0091-5

COLOMBO, N.; COVIELlA, A.; HAGIWARA, J.C. A novel source of cytoplasmic male sterility in Calibrachoa pubescens. Ornamental Horticulture, v.23, n.3, p.311318, 2017. DOI: http://dx.doi.org/10.14295/oh.v23i3.1061

CORRIVEAU, J.L.; COLEMAN, A.W. Rapid screening method to detect potential biparental inheritance of plastid DNA and results for over 200 angiosperm species. American Journal of Botany, v.75, n.10, p.1443-1458, 1988. DOI: https://doi.org/10.1002/j.1537-2197.1988. tb11219.x

DEBENER, T.H. Molecular tools for modern ornamental plant breeding and selection. Acta Horticulturae, v.552, p.121-128, 2001. DOI: https://doi.org/10.17660/ ActaHortic.2001.552.12

DOYLE, J.J.; DOYLE, J.L. A rapid DNA isolation procedure for small quantities of fresh leaf tissue. Phytochemical Bulletin, v.19, n.1, p.11-15, 1987.

DWIVEDI, S.; PEROTTI, E.; ORTIZ, R. Towards molecular breeding of reproductive traits in cereal crops. Plant Biotechnology Journal, v.6, p.529-559, 2008. DOI: https://doi.org/10.1111/j.1467-7652.2008.00343.x 
FERREIRA, R.R.; SANTOS, C.A.F. Partial success of marker-assisted selection of ' $A$ ' and ' $\mathrm{B}$ ' onion lines in Brazilian germplasm. Scientia Horticulturae, v.242, p.110-115, 2018. DOI: https://doi.org/10.1016/j. scienta.2018.08.002

GANGA, M.; JAYALAKSHMI, S.; JEGADEESWARI, V.; PADMADEVI, K.; JAWAHARLAL, M. Petunia. In: KOLE, C. Wild Crop Relatives: Genomic and Breeding Resources, Plantation and Ornamental Crops. Berlin: Springer-Verlag, 2011. p.209-242. DOI: https://doi. org/10.1007/978-3-642-21201-7_11

GILLMAN, J.D.; BENTOLILA, S.; HANSON, M.R. Cytoplasmic male sterility and fertility restoration in Petunia. In: GERATS, T., STROMMER, J. Petunia. New York: Springer, 2009. p. 107-129.

IZHAR, S. Cytoplasmic male sterility in petunia: III. Genetic control of microsporogenesis and male fertility restoration. Journal of Heredity, v.69, n.1, p.22-26, 1978. DOI: https://doi.org/10.1093/oxfordjournals.jhered. a108877

KIM, Y; ZHANG, D. Molecular control of male fertility for crop hybrid breeding. Trends in Plant Science, v.23, n.1, p.53-65, 2018. DOI: https://doi.org/10.1016/j. tplants.2017.10.001

MOGENSEN, H.L. The hows and whys of cytoplasmic inheritance in seed plants. American Journal of Botany, v.83, n.3, p.383-404, 1996. DOI: https://doi. org/10.1002/j.1537-2197.1996.tb12718.x

NIVISON, H.T.; SUTTON, C.A.; WILSON, R.K.; HANSON, M.R. Sequencing, processing, and localization of the petunia CMS-associated mitochondrial protein. The Plant Journal, v.5, n.5, p.613-623, 1994. DOI: https://doi. org/10.1111/j.1365-313X.1994.00613.x
ROBBINS, T.P.; HARBORD, R.M.; SONNEVELD, T.; CLARKE, K. The molecular genetics of selfincompatibility in Petunia hybrida. Annals of Botany, v.85, Suppl.A, p.105-112, 2000.

SWAMY, B.N.; HEDAU, N.K.; CHAUDHARI, G.V.; KANT, L.; PATTANAYAK, A. CMS system and its stimulation in hybrid seed production of Capsicum annuum L. Scientia Horticulturae, v.222, p.175-179, 2017. DOI: https://doi.org/10.1016/j.scienta.2017.05.023

SHU, J.; LIU, Y.; LI, Z.; ZHANG, L.; FANG, Z.; YANG, L.; ZHUANG, M.; ZHANG, Y.; LV, H. Detection of the diversity of cytoplasmic male sterility sources in broccoli (Brassica oleracea varitalica) using mitochondrial markers. Frontiers in Plant Science, v.7, article 927, 2016. DOI: https://doi.org/10.3389/fpls.2016.00927

TABERLET, P. ; GIELLY, L. ; PAUTOU, G. ; BOUVET, J. Universal primers for amplification of three non-coding regions of chloroplast DNA. Plant Molecular Biology, v.17, n.5, p.1105-1109, 1991. DOI: https://doi.org/10.1007/ BF00037152

TSUKAMOTO, T.; ANDO, T.; KOKUBUN, H.; WATANABE, H.; SATO, T.; MASADA, M.; MARCHESI, E.; KAO, T. Breakdown of self-incompatibility in a natural population of Petunia axillaris caused by a modifier locus that suppresses the expression of an S-RNase gene. Sexual Plant Reproduction, v.15, n.5, p.255-263, 2003. DOI: https://doi.org/10.1007/s00497-002-0161-5

YOUNG, E.G.; HANSON, M.R. A fused mitochondrial gene associated with cytoplasmic male sterility is developmentally regulated. Cell, v.50, n.1, p.41-49, 1987. DOI: https://doi.org/10.1016/0092-8674(87)90660-X 